\title{
Students' Levels of Recognition of Parallelogram and of Establishment of Connections
}

\author{
Abdullah Çağrı Biber ${ }^{1, *}$, Abdulkadir Tuna ${ }^{1}$, İfan Dağdelen ${ }^{1} \&$ İbrahim Kepceoğlu ${ }^{1}$ \\ ${ }^{1}$ Department of Science and Mathematics Education, Kastamonu University, Kastamonu, Turkey \\ *Correspondence: Department of Science and Mathematics Education, Kastamonu University, Kastamonu, Turkey. \\ Tel: 90-366-280-3411. E-mail: acbiber@gmail.com
}

Received: May 21, 2019

Accepted: June 19, 2019 Online Published: July 21, 2019

doi:10.5430/jct.v8n3p1

URL: https://doi.org/10.5430/jct.v8n3p1

\begin{abstract}
In this research, it is aimed to explore how students are able to define parallelogram and to establish relations with other quadrilaterals at each class level comparatively. Case study is chosen as the methodology of this study and the participants of the study are 120 middle school students from a state middle school in Turkey. Two open-ended questions are used to gather data and the descriptive analysis is used. The results of the study show that the students determine parallelogram based on its typical image. Furthermore, students have not fully grasp the hierarchical relation between these special quadrilaterals in their minds.
\end{abstract}

Keywords: mathematics education, middle school students, parallelogram, quadrilaterals

\section{Introduction}

Geometry is an important branch of mathematics to teach. The study of geometry contributes to helping students develop the skills of visualisation, critical thinking, intuition, perspective, problem-solving, conjecturing, deductive reasoning, logical argument and proof (Jones, 2002). Baki (2008) summarizes the general objectives of geometry education as recognizing the properties of geometric shapes in plane and space, exploring the relationships among them, defining the locus, explaining their transformations and proving geometrical propositions.

Geometry is closely related to everyday life. As a matter of fact, geometry is used to solve many problems that people encounter in daily life (frame making, wallpapering, painting, building, etc.) (Altun, 2008). Geometry also has an important place in primary and secondary school mathematics programs due to reasons such as critical thinking, the development of problem solving skills, the development of aesthetic and artistic feelings, and the teaching of other subjects of mathematics (Baykul, 2005). Despite the importance of geometry, it is observed that the students' knowledge, skills and thinking levels on geometry are not sufficient and they have difficulties in learning geometric concepts (Özkan, 2015; Dane ve Başkurt, 2012; Aktaş \& Aktaş, 2012; Ergün, 2010; Ubuz \& Üstün, 2003; Monoghan, 2000; De Villers, 1994).

Students' inadequacies and learning difficulties are also seen in the results of the International Mathematics and Science Research (TIMSS) and the International Student Assessment Program (PISA). According to the results of TIMSS 2015, Turkey is 36th among 49 countries in the fourth grade and 24th among 39 countries in the eighth grade (URL1, 2017). Similarly, according to PISA 2015 results, Turkey is 49th among 70 countries (MoNE, 2016). When TIMSS or PISA questions are examined, it is seen that there are questions about geometry topics. When these questions are examined, it is seen that the students should have some skills such as internalizing the definitions of geometric concepts, drawing skills of these concepts, using geometrical reasoning and thinking skills, and being aware of the relation of geometry to everyday life. As a matter of fact, Aydoğdu İskenderoğlu and Baki (2011) stated that the purpose of the PISA questions is to measure skills such as reasoning, analyzing, communicating, problem solving and mathematical situations as well as how they use this information in their daily life. Therefore, considering the academic studies about TIMSS and PISA results, it can be said that the students of Turkiye have problems in their conceptual learning in geometry subjects. One of the concepts of geometry in which students are having difficulty learning is the quadrilateral. 
Quadrilaterals contribute to the development of geometric thinking by enabling students to have a number of mathematical skills such as defining mathematically, classifying, establishing relationships between quadrants. As a matter of fact, Fujita and Jones (2007) view the hierarchical classification of quadrangles as an area that will enable the development of geometric thinking to proceed.

Students' geometric thinking is developed by following certain levels. Van Hiele (1986) defined these levels in a hierarchically progressive way and proposed a model. At the end of secondary school, students are expected to have reached the third level. At the first level (Visual Level), students are interested in the shape of the exterior image and cannot see geometric features. At the second level (Analysis Level), they begin to distinguish features; but they cannot relate to geometric forms. At the third level (Pre-Logical Level), students begin to see the relation between the features of geometric shapes. That is, the student begins to notice that a square is a parallelogram, and that all the properties of the parallelograms are also the ones of the square (Baykul, 2005). In his study, Fujita (2012) presented fifteen quadrilaterals to the students and asked them to choose parallelograms. In addition, the number of parallelograms that students select correctly and which quadrilateral is considered as parallelograms are evaluated in classifying by determining the level of parallelogram understanding of that student. When the work of the Van Hiele Geometry Thinking Levels Model and Fujita (2012) are evaluated together, it can be explained that the mathematical definition of the student's choice of geometric shapes presented to him visually by matching them with the shape in his mind.

When the 2017 secondary school mathematics curriculum is examined, in the 5th grade, the achievements related to the basic features of rectangular, parallelogram, rhombus and patchwork are included. In the 6th grade, there are some achievements related to the calculation of the area of a parallelogram. Rectangles, parallelograms, trapezoids and rhombuses are studied in the 7th grade. In the 8th grade, it is seen that there is no achievement related to the quadrilaterals (MoNE, 2017).

When primary and secondary school mathematics curricula are examined, students are expected to be able to define geometric shapes and properties, to classify them, to recognize the relationships between shapes and to make geometric drawings (MoNE, 2013; 2015). However, when examined academic studies in this area students geometric shapes, students had difficulty in thinking each quadrilateral independently and separately from each other (Aydogdu, 2003), in classifying them (Berkün, 2011; Erez and Yerushalmy, 2006; Fujita and Jones, 2006; Monaghan, 2000 , Okazaki and Fujita, 2007; Olkin and Aydogdu, 2003, Üstün \& Ubuz, 2004), in the transition between them (Ergun, 2010; Aktas and Cansız Aktas, 2012) and in defining them (De Villiers, 1994; Erez and Yerushalmy, 2006, Ergün, 2010, Fujita and Jones, 2006, Okazaki and Fujita, 2007). For example in the study of Aktas and Cansiz Aktas (2011), eighth grade students easily recognized special quadrilaterals, but they are not good enough to identify them. Similarly in the study of Fujita (2012), secondary students have difficulties in understanding the hierarchical relationships between quadrilaterals. In Ergun's study (2010) seventh graders students often use the Prototypical shapes while defining polygons. In his work, Başışı (2010) work with 5th grade students and stated that when describing parallelism, students ignore that parallelograms are a polygon whose sides are parallel to each other. Likewise, Cansız Aktaş and Aktas (2012) discussed how 10th grade students understand parallelograms. In their study, they have found that only $11 \%$ of students correctly determine the parallelogram between given quadrilaterals. Furthermore very little percentage of students recognize that square, rectangle and rhombus is also a parallelogram and only $28,4 \%$ of students state correct definition of parallelogram.

When the above explanations and studies are evaluated together, it is important to find out at what level middle school students recognize these concepts and how they relate to each other in order to determine their understanding of geometric concepts. As a matter of fact, in many studies conducted, it has been revealed that not only the students but also teachers and prospective teachers have problems in defining geometrical concepts and establishing relationships. From this point of view, it is known that teachers and prospective teachers carry the problems they had with quadrants from their previous education (Pusey, 2003). In this context, it is thought that it is important to determine the conceptual learning of the geometric concepts of the middle school students (5th, 6th, 7th, and 8th grade students). As far as it is not found any research about a comparison between classes levels in the literature. Indeed Ergün (2010) stated that research is needed to determine whether polygon detection, identification and classification patterns change according to the class level. In the study of Ergün (2010), only parallelograms were given to students in order to gain in-depth knowledge about the conceptual learning of geometry. In contrast in the current research, it is aimed to explore how students are able to define parallelogram and to establish relations with other quadrilaterals (square, rectangle, rhombus, trapezoid) at each class level comparatively. The research problems of this study are: 
1. What is the level of recognition of middle school students' parallelograms and is there any difference in terms of students' grades?

2. How are middle school students correlating parallelogram with other some special quadrilaterals?

3. Is there any relation between the level of recognition of middle school students' parallelograms and the skills of the middle school students to associate parallelograms to other some special quadrilaterals?

\section{Methodology}

\subsection{Research Design}

According Cohen, Manion and Morrison (2000), case studies involve the observation of the characteristics of an individual unit - a child, a clique, a class, a school or a community for a quite specific purpose. This study is also best accomplished through the case study methodology because of our intent to determine the level of recognition of middle school students' parallelograms and how they correlate parallelograms with other special quadrilaterals.

\subsection{Participants}

Being practical and time-saving, the convenience sampling method is chosen for this study because one of the researchers is a mathematics teacher in a state middle school in Samsun. The participants of the study are 120 students from this school. According to the aim of the study, students are chosen from different grade levels in order to compare their level of recognition of parallelograms. The demographic properties of working group are given in the following Table1.

Table 1. Demographic Properties of Working Group

\begin{tabular}{llllll}
\hline Grade & 5 th & 6 th & 7 th & 8 th & Total \\
\hline Number of students & 30 & 30 & 28 & 32 & 120 \\
\hline
\end{tabular}

\subsection{Data Collection Tool}

Two open ended questions with the aim of determining the students' ability to define parallelogram and to establish relations with other quadrilaterals at each class level comparatively are used to gather data (see Appendix-1). One of the questions is taken from the study of Fujita (2012); because in the study of Fujita (2012), the understanding of the inclusion relations between quadrilaterals may be understood and be examined through certain levels by considering Van Hiele's visual, analytical, informal deductive and deductive levels. Here, in the current study, since the aim is to determine students' level of recognition of parallelograms, the question used in the study of Fujita (2012) is considered to be the best one. Other question is prepared by researches after examining relevant literature, mathematics curricula and textbooks. In order to ensure the reliability of the questions, they are evaluated by experts that are mathematics academicians and teachers.

\subsection{Analysis of Data}

The document analysis method is used to analyze data. Document analysis is a systematic procedure for reviewing or evaluating documents - both printed and electronic (computer-based and Internet-transmitted) material. Like other analytical methods in qualitative research, document analysis requires that data be examined and interpreted in order to elicit meaning, gain understanding, and develop empirical knowledge (Bowen, 2009). Students' written answers to two open-ended questions are considered as documents in this study.

For the analysis of students' answers to question1, Fujita's (2012) assessment criteria are used. These criteria are given in the following Table 2 and Table 3. 
Table 2. Students' Level of Understanding Parallelogram (Fujita, 2012)

\begin{tabular}{ll}
\hline Level & Description \\
\hline D-P-Hierarchical & $\begin{array}{l}\text { Learners can accept squares, rectangles and rhombi are also parallelograms. 'The opposing direction } \\
\text { inclusion relationship' of definitions and attributes is understood }\end{array}$ \\
D-P-Partial Prototypical & $\begin{array}{l}\text { Learners have begun to extend their figural concepts. For example, they accept rhombi are also } \\
\text { parallelograms but not squares and rectangles. Their judgement would be likely to be prototypical type } 2\end{array}$ \\
D-P-Prototypical & $\begin{array}{l}\text { Learners who have their own limited personal figural concepts. Their judgement would be either } \\
\text { prototypical type } 1 \text { or } 2\end{array}$ \\
Level 0 & Learners do not have basic knowledge of parallelograms \\
\hline
\end{tabular}

Table 3. Evaluation Criteria for Question1

\begin{tabular}{lllll}
\hline Question & D-P- Hierarchical & D-P-Partial Prototypical & D-P-Prototypical & Level 0 \\
\hline & At least ten of the following: $1,2,4$, & At least six of $1,5,6,9,11,14$, & At least three of & Other answers based on \\
& $5,6,7,9,11,13,14,15$ and none of & 15 or eight of $1,2,4,5,6,7,9$, & the following: 1, & wrong definition, or \\
& the following: $3,8,10,12$ & $11,13,14,15$ and none of the & $6,9,14$; and none & choose two of $3,8,10$, \\
& & following: $3,8,10,12$ & of the following: & 12 \\
\hline
\end{tabular}

Examining Table 3, students should not choose rectangles 3, 8, 10, and 12 as parallelograms for Prototypical, Partial Prototypical, and Hierarchical levels. In addition, eleven of the fifteen quadrants given are parallelograms. If students choose at least 10 of them, they are assigned to Hierarchical Level. If they choose 6-8 of them, they are assigned to Partial Prototypical Level. If they choose 3-5, they are assigned to Prototypical Level, otherwise they are assigned to Level 0.

In the question2, students are asked to establish the relationship between parallelograms and other special quadrilaterals (trapezoid, rhombus, rectangle, square). The data from these questions is subjected to content analysis. Cohen, Manion and Morrison (2007) stated that content analysis is a method of analysis that consists of editing, classifying, comparing texts and extracting theoretical conclusions from texts. The answers given by the students to the proposals were carefully examined and the texts were arranged and divided into two categories: correct and incorrect. Then the correct answers of the proposals are also classified into two subcategories: "there is explanation" and "no explanation or missing". Content analysis is according to Yıldırım and Şimşek (2008), to describe the similarity of data in the context of specific themes and data, and interpretation of them as presented by the reader in a way that the reader can understand.

For each question, appropriate tables are created and frequencies and percentages are included. In addition, the answers by students are directly given. The answers for each question are independently analyzed by two different researchers, and necessary subcategories were created. The obtained data are also checked by a third researcher. Discrepancies between them are reviewed again and data analysis is finalized. In these comparisons, the percentage of incompatibility that Miles and Huberman (1994) suggested, reliability (Reliability = Opinion Unity / (Opinion Unity + Opinion Separation)) is calculated for each category separately. The percentage of compliance for each question is given in Table 4 below.

Table 4. Percentage of Incompatibility

\begin{tabular}{ll}
\hline Question & Percentage \\
\hline Q1 & $87 /(87+3)=0,96$ \\
Q2 & $\mathbf{7 6} /(\mathbf{7 6}+\mathbf{1 4})=\mathbf{0 , 8 4}$ \\
\hline
\end{tabular}

As seen in table 4, all calculated percentages are higher than $70 \%$ and therefore analysis in the study can be considers as reliable (Miles \& Huberman, 1994). Besides Pearson Chi-Square analysis is conducted to determine students' ability to establish the relationship between parallelograms and other special quadrilaterals. A significance level of 0.05 was considered in all analyzes. 


\section{Findings}

The data in this study is investigated under the three following categories: "defining parallelogram", "establishing connections between parallelograms and some special quadrilaterals" and "students' skills of establishment these connections".

\subsection{Defining Parallelograms}

In the first questions, participant students are asked to choose parallelograms between given 15 quadrilaterals. Students' level of determining parallelograms is given in the following Table 5.

Table 5. Students' Level of Determining Parallelograms

\begin{tabular}{lllllllll}
\hline Grades & 5th & \multicolumn{3}{c}{ 6th } & \multicolumn{3}{c}{ 7th } & \multicolumn{3}{c}{ 8th } \\
\hline Levels & $\mathrm{f}$ & $\%$ & $\mathrm{f}$ & $\%$ & $\mathrm{f}$ & $\%$ & $\mathrm{f}$ & $\%$ \\
D-P-Hierarchical & 3 & 10 & 1 & 3.4 & 17 & 60.8 & 13 & 40.6 \\
D-P-Partial Prototypical & 3 & 10 & 7 & 23.3 & 5 & 17.8 & 7 & 21.8 \\
D-P-Prototypical & 11 & 37 & 16 & 53.3 & 2 & 7.2 & 6 & 18.8 \\
Level 0 & 13 & 43 & 6 & 20.0 & 4 & 14.2 & 6 & 18.8 \\
\hline
\end{tabular}

As seen in Table $5,10 \%$ of $5^{\text {th }}$ grade students, $3.4 \%$ of $6^{\text {th }}$ grade students, $60.8 \%$ of $7^{\text {th }}$ grade students and $40.6 \%$ of $8^{\text {th }}$ grade students have determined correctly at least 10 of 11 parallelograms in the given set of 15 quadrilaterals. Also, 53.3\% of $6^{\text {th }}$ grade students have chosen the Prototypical of parallelograms that are 1., 6., 9. and 14 . quadrilaterals in the given set. Besides, $43 \%$ of $5^{\text {th }}$ grade students, $20 \%$ of $6^{\text {th }}$ grade students, $14.2 \%$ of $7^{\text {th }}$ grade students and $18.8 \%$ of $8^{\text {th }}$ grade students haven't determined correctly parallelograms. In other words, they haven't chosen at least 3 parallelograms in the given set.

Table 6. Students' Consideration of Given Quadrilateral as Parallelogram in the Question1

\begin{tabular}{|c|c|c|c|c|c|c|c|c|c|c|c|c|c|c|c|c|}
\hline Grade & No & 1 & 2 & $3 *$ & 4 & 5 & 6 & 7 & 8* & 9 & 10 * & 11 & $12 *$ & 13 & 14 & 15 \\
\hline 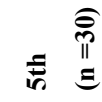 & $\%$ & 77 & 47 & 37 & 33 & 43 & 87 & 47 & 17 & 70 & 27 & 23 & 30 & 67 & 80 & 33 \\
\hline 总 & $\%$ & 100 & 13 & 17 & 13 & 43 & 100 & 13 & 3 & 84 & 23 & 13 & 17 & 27 & 97 & 46 \\
\hline$=\stackrel{\substack{\mathbb{N} \\
\|}}{\Xi}$ & $\%$ & 93 & 78 & 7 & 68 & 71 & 93 & 71 & 7 & 96 & 7 & 86 & 3 & 78 & 90 & 71 \\
\hline 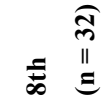 & $\%$ & 100 & 81 & 3 & 75 & 75 & 97 & 66 & 0 & 97 & 3 & 72 & 25 & 84 & 100 & 66 \\
\hline
\end{tabular}

* Marked quadrilaterals aren’t parallelograms

As seen in Table 6, students have most correctly chosen the Prototypical of parallelograms that are 1., 6., 9. and 14. quadrilaterals (Quadrilateral numbered 1 has been chosen by $77 \%$ of $5^{\text {th }}$ grade students, $100 \%$ of $6^{\text {th }}$ grade students, $93 \%$ of $7^{\text {th }}$ grade students and $100 \%$ of $8^{\text {th }}$ grade students; quadrilateral numbered 6 has been chosen respectively by $\%$ $87-\% 100-\% 93-\% 97$; quadrilateral numbered 9 has been chosen respectively by $\% 70-\% 84-\% 96-\% 97$; quadrilateral numbered 14 has been chosen respectively \% 80 - \% 97 - \% 90 - \% 100).

In the given set of quadrilaterals, there are some special forms of parallelograms such as square, rhombus and rectangles. Quadrilaterals numbered 4 and 11 which are squares have been chosen by $28 \%$ of $5^{\text {th }}$ grade students, $13 \%$ of $6^{\text {th }}$ grade students, $77 \%$ of $7^{\text {th }}$ grade students and $73.5 \%$ of $8^{\text {th }}$ grade students. Quadrilaterals numbered $4,5,11$ and 15 which are rhombus have been chosen by $28 \%$ of $5^{\text {th }}$ grade students, $29 \%$ of $6^{\text {th }}$ grade students, $74 \%$ of $7^{\text {th }}$ grade 
students and $72 \%$ of $8^{\text {th }}$ grade students. Quadrilaterals numbered 2, 4, 7, 11 and 13 which are rectangles have been chosen by $35 \%$ of $5^{\text {th }}$ grade students, $15.8 \%$ of $6^{\text {th }}$ grade students, $76.2 \%$ of $7^{\text {th }}$ grade students and $75.6 \%$ of $8^{\text {th }}$ grade students. Also in the given set of quadrilaterals, there are some quadrilaterals that are not parallelograms (Quadrilaterals numbered 3, 8, 10 and 12). These quadrilaterals have been chosen by $28 \%$ of $5^{\text {th }}$ grade students, $15 \%$ of $6^{\text {th }}$ grade students, $6 \%$ of $7^{\text {th }}$ grade students and $7.8 \%$ of $8^{\text {th }}$ grade students. Strikingly, $37 \%$ of $5^{\text {th }}$ grade students have chosen quadrilateral numbered 3,23\% of $6^{\text {th }}$ grade students have chosen quadrilateral numbered 10 and $25 \%$ of $8^{\text {th }}$ grade students have chosen quadrilateral numbered 12.

\subsection{Establishing Connections between Parallelograms and Some Special Quadrilaterals}

In the question 2, four statements are given to the students in order to determine how students establish connections between parallelograms and some special quadrilaterals (trapezoid, rhombus, rectangle, square). Students are also asked to explain their answers in detail. Students' answers are categorized in the following Table 7. When analyzing the answers, the following answers are considered as "correct": "No" for the statement "Trapezoid is a parallelogram", "Yes" for other statements "Rhombus is a parallelogram", "Rectangle is a parallelogram" and "Square is a parallelogram". All other answers for the statements are considered as "incorrect".

In the following Table 7, some examples of students' answers for statements are given.

Table 7. Examples of Students' Answers

\begin{tabular}{|c|c|c|}
\hline Statement & Evaluation & Examples \\
\hline Trapezoid is a parallelogram & Correct & 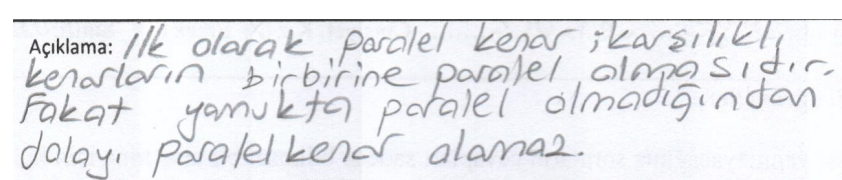 \\
\hline
\end{tabular}

English: Opposing sides of parallelograms must be parallel, but trapezoid has non-parallel sides.

Incorrect

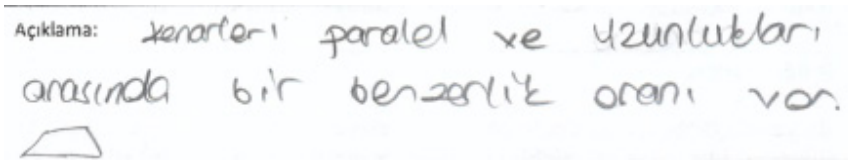

Rhombus is a parallelogram Correct

English: The sides are parallel and there is a similarity ratio between side lengths.

Incorrect

Aciklama: Cürkü karsilikl, kerarlar, poraleldir.

English: Because opposing sides is parallel,

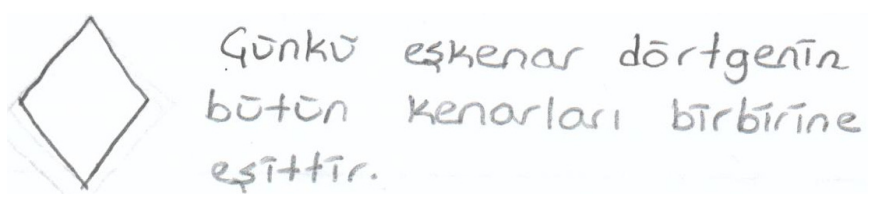

English: All sides of rhombus are equal.

Rectangle is a parallelogram Correct

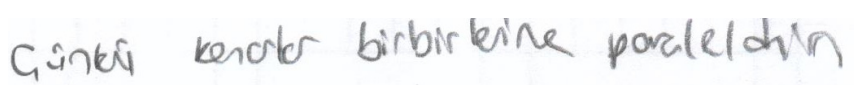

English: All sides of rectangle are parallel.

Incorrect

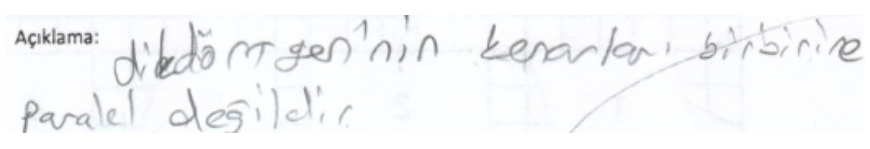

English: The sides of rectangle are not parallel to each other. 
Table 7 continued

\begin{tabular}{|c|c|c|c|}
\hline $\begin{array}{l}\text { Square is } \\
\text { parallelogram }\end{array}$ & $\mathbf{a}$ & Correct & $\begin{array}{l}\text { Açiklama: Gülki knextan birbink paralel uzatil- } \\
\text { diginda kesismilyer. Kossilikl kencrlan parclel. }\end{array}$ \\
\hline
\end{tabular}

English: All sides of square are parallel. If they are extended, they are not coincided. Opposing sides are parallel.

Incorrect

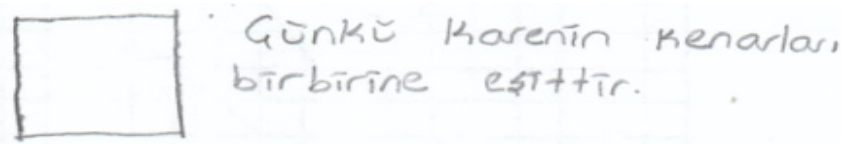

English: Because the sides of a square are equal to each other.

The evaluations of the students for the statements are given in Table 8. The explanations given by those who have made the correct assessment to see how well the conceptual meaning is achieved by the student is also confirmed.

Table 8. Students' Level of Establishment of Connections between Parallelograms and Some Special Quadrilaterals

\begin{tabular}{|c|c|c|c|c|c|c|}
\hline \multirow[t]{2}{*}{ Statement } & \multirow[t]{2}{*}{ Evaluation } & \multirow[t]{2}{*}{ Explanation } & 5th & 6th & 7 th & 8th \\
\hline & & & $\%$ & $\%$ & $\%$ & $\%$ \\
\hline \multirow{3}{*}{$\begin{array}{l}\text { Trapezoid is a } \\
\text { parallelogram }\end{array}$} & Correct & & 47 & 27 & 21 & 19 \\
\hline & Incorrect & Yes & 30 & 26 & 36 & 41 \\
\hline & & No or incomplete & 23 & 47 & 43 & 40 \\
\hline \multirow{3}{*}{$\begin{array}{l}\text { Rhombus is a } \\
\text { parallelogram }\end{array}$} & Correct & Yes & 20 & 14 & 39 & 47 \\
\hline & & No or incomplete & 30 & 20 & 40 & 40 \\
\hline & Incorrect & & 50 & 66 & 21 & 13 \\
\hline \multirow{3}{*}{$\begin{array}{l}\text { Rectangle is a } \\
\text { parallelogram }\end{array}$} & Correct & Yes & 20 & 13 & 39 & 50 \\
\hline & & No or incomplete & 46 & 7 & 43 & 40 \\
\hline & Incorrect & & 34 & 80 & 18 & 10 \\
\hline \multirow{3}{*}{$\begin{array}{l}\text { Square is a } \\
\text { parallelogram }\end{array}$} & Correct & Yes & 20 & 3 & 39 & 40 \\
\hline & & No or incomplete & 33 & 14 & 43 & 48 \\
\hline & Incorrect & & 47 & 83 & 18 & 12 \\
\hline
\end{tabular}

As seen in Table 8 , for the statement "Trapezoid is a parallelogram", $53 \%$ of 5 th grade students, $73 \%$ of 6 th grade students, $79 \%$ of 7 th grade students and $81 \%$ of 8 th grade students have answered "no". Here, the increase in correct answers via grades is interesting. When the percentages of totally correct mathematical explanation for "no" answers in the first statement students' explanations were examined, it was seen that 8th grade students made the most accurate $(41 \%)$ mathematically correct explanations. This is important for showing the mathematical maturity of Grade 8 students.

For the statement "Rhombus is a parallelogram", $50 \%$ of 5 th grade students, $34 \%$ of 6 th grade students, $79 \%$ of 7 th grade students and $87 \%$ of 8 th grade students have answered "yes". There is a steady residual observed in the correct response rates of the students, except for the 6 classes. The percentages of totally correct mathematical explanation for "yes" answers in the second statement are $20 \%$ for 5 th grade, $14 \%$ for 6 th grade, $39 \%$ for 7 th grade and $47 \%$ for 8th grade. This situation is parallel to the proportional distribution of students' correct answers and has been at least 6th grade students who support the answer with an explanation.

For the statement "Rectangle is a parallelogram", $66 \%$ of 5 th grade students, $20 \%$ of 6 th grade students, $82 \%$ of 7 th grade students and $90 \%$ of 8th grade students have answered "yes". Here also, the correct answers show that 6th grade students are remarkably lagging behind other classes. The percentages of totally correct mathematical explanation for "yes" answers in the second statement are $20 \%$ for 5 th grade, $13 \%$ for 6 th grade, $39 \%$ for 7 th grade and $50 \%$ for 8 th grade. 
For the statement "Square is a parallelogram", $53 \%$ of 5 th grade students, $17 \%$ of 6 th grade students, $82 \%$ of 7 th grade students and $88 \%$ of 8 th grade students have answered "yes". In this statement, 6 grade students are the group giving the least right answer. The percentages of totally correct mathematical explanation for "yes" answers in the second statement are $20 \%$ for 5 th grade, $13 \%$ for 6 th grade, $39 \%$ for 7 th grade and $40 \%$ for 8 th grade. It seems that 6 th grade students still hesitate to give explanation in this statement.

Relationship between students' determination of parallelograms and skills of establishment connections between parallelograms and other some special quadrilaterals

This part consists of findings about the relationship between how students define parallelograms and how they determine the connection between parallelograms with some special quadrilaterals.

Table 9. Chi-Square Test Results about Students' Answers to Statement "Trapezoid is a Parallelogram" According to Their Level of Determining Parallelograms

\begin{tabular}{lllc}
\hline & Wrong answers & Correct answers & Total \\
\hline Level 0 & 17 & 12 & 29 \\
D-P-Prototypical & 9 & 26 & 35 \\
D-P- Partial Prototypical & 2 & 20 & 22 \\
D-P- Hierarchical & 4 & 30 & 34 \\
Total & 32 & 88 & 120 \\
\hline
\end{tabular}

$x^{2}=22.494, s d=3, p=0.000$

As seen in Table 9, 12 of level 0 students, 26 of D-P-prototypical students, 20 of D-P-partial prototypical students and 30 of D-P-hierarchical students have given correct answer to this statement. The relationship between students' level of determining parallelograms and answers to this statement has been found statistically significant ( $\mathrm{x} 2=$ 22.494 and $\mathrm{p}=0.000$ ). Therefore, as the parallel recognition level increases, it is seen that there is an increase in the accuracy of the answers given by students.

Table 10. Chi-Square Test Results about Students' Answers to Statement "Rhombus is a Parallelogram" According to Their Level of Determining Parallelograms

\begin{tabular}{lllc}
\hline & Wrong answers & Correct answers & Total \\
\hline Level 0 & 13 & 16 & 29 \\
D-P-Prototypical & 18 & 17 & 35 \\
D-P- Partial Prototypical & 12 & 10 & 22 \\
D-P- Hierarchical & 4 & 30 & 34 \\
Total & 47 & 73 & 120 \\
\hline
\end{tabular}

$x^{2}=15.497, s d=3, p=0.001$

As seen in Table 10, 16 of level 0 students, 17 of D-P-prototypical students, 10 of D-P-partial prototypical students and 30 of D-P-hierarchical students have given correct answer to this statement. The relationship between students' level of determining parallelograms and answers to this statement has been found statistically significant $(\mathrm{x} 2=$ 15.497and $p=0.001)$. Here also, as the parallel recognition level increases, it is seen that there is an increase in the accuracy of the answers given by students. 
Table 11. Chi-Square Test Results about Students' Answers to Statement "Rectangle is a Parallelogram" According to Their Level of Determining Parallelograms

\begin{tabular}{lllc}
\hline & Wrong answers & Correct answers & Total \\
\hline Level 0 & 9 & 20 & 29 \\
D-P-Prototypical & 18 & 17 & 35 \\
D-P- Partial Prototypical & 10 & 12 & 22 \\
D-P- Hierarchical & 2 & 32 & 34 \\
Total & 39 & 81 & 120 \\
\hline
\end{tabular}

$x^{2}=18.408, s d=3, p=0.000$

As seen in Table 11, 20 of level 0 students, 17 of D-P-prototypical students, 12 of D-P-partial prototypical students and 32of D-P-hierarchical students have given correct answer to this statement. The relationship between students' level of determining parallelograms and answers to this statement has been found statistically significant $(\mathrm{x} 2=$ 18.408 and $\mathrm{p}=0.000)$.

Table 12. Chi-Square Test Results about Students' Answers to Statement "Square is a Parallelogram" According to Their Level of Determining Parallelograms

\begin{tabular}{llll}
\hline & Wrong Answers & Correct Answers & Total \\
\hline Level 0 & 10 & 19 & 29 \\
D-P-Prototypical & 19 & 16 & 35 \\
D-P- Partial Prototypical & 13 & 9 & 22 \\
D-P- Hierarchical & 4 & 30 & 34 \\
Total & 46 & 74 & 120 \\
\hline
\end{tabular}

$x^{2}=18.113, s d=3, p=0.000$

As seen in Table 12, 19 of level 0 students, 19 of D-P-prototypical students, 9 of D-P-partial prototypical students and 30of D-P-hierarchical students have given correct answer to this statement. The relationship between students' level of determining parallelograms and answers to this statement has been found statistically significant $(\mathrm{x} 2=$ 18.113 and $\mathrm{p}=0.000)$.

\section{Conclusions, Discussions and Implications}

The results of secondary school students' selection of parallelograms in the given fifteen quadrilaterals shows that most of 5th grade students are of the Prototypical level and level 0, that almost half of the 6th grade students are of the Prototypical level, that more than half of the 7th grade students are of the hierarchical level, and that 8th grade students are distributed at almost. According to these results, it is seen that students in all class levels are not in the expected level to determine 11 of parallelograms from given quadrilaterals. Comparisons among classes show that 7 th grade students are more successful than other class levels. This situation is considered to occur due to the fact that in the 7th grade mathematics program, quadrilaterals are allocated more space than other class levels (MEB, 2015).

When the selection percentage of parallelograms in the given fifteen quadrilaterals by the students are examined, it is seen that the quadrilaterals numbered 1,6,9 and 14, which are the typical image of parallelogram, have been chosen by students at the highest percentage. This result shows that the students determine parallelogram based on its typical image. This result originates from the fact that in textbooks, test books and similar sources, it is often the case that parallelograms of typical images involved, and that teachers often use the typical parallelogram image during teaching. Likewise, Aktaş and Aktas (2012) reached the result that 9th grade students chose the quadrilaterals numbered 1, 6, 9 and 14. Similar results were obtained in the studies of Okazaki and Fujita (2007), Fujita and Jones (2007), Fujita (2012), Karakuş and Erşen (2013). 
The choice of the typical parallelogram images at all class levels shows that the class levels do not notice this choice. This shows that even though the class level has increased, they have made choices by acting with the conceptual images that existed in the minds of the students. As a matter of fact, the results of Berkün (2011) overlap with the results of the fifth and seventh grade students who did not depend on the class level of the Prototypicals and the images belonging to the quadrilaterals. Likewise, Fujita \& Jones (2007) noted that in their work, students were paying attention to their prior learning knowledge while determining polygons.

It has been seen that the percentage of students choosing square, rectangular and rhombus, which is a special form of parallelogram, increases with the increase of the class level of the students. However, the 5th grade students were found to be more successful than the 6th grade students. This is thought to be due to the fact that the quadrilaterals in the 5th grade mathematics program are more likely to occupy more space than the 6th grade mathematics program. Increasing the class level is an expected result of increasing the percentage of students to realize that square, rectangle and rhombus are a special case of parallelogram. Because the level of students' geometric thinking is progressing, they also face more problems involving quadrilaterals in mathematics lessons. It is thought that the quadrilaterals in the 7th grade are occupied more in the mathematics program (MEB, 2015) and that the students may have passed to the 2nd level of the Van Hiele Geometry Thinking Levels provided with appropriate learning environments.

When the selection percentages of non-parallelogram quadrilaterals $(3,8,10,12)$ of students are examined, students generally distinguish quadrilaterals which are not parallelogram with increase of class level. However, when it is taken into consideration that almost one of four 5th grade students have chosen quadrilateral numbered 3, 6th grade students have chosen quadrilateral numbered 10 and 8th grade students have chosen quadrilateral numbered 12, the students are experiencing a number of difficulties. This result is in agreement with the results of Aktas and Aktas (2012) and Fujita (2012).

In the second question, students were asked about the relationship between parallelograms and some other special quadrilaterals. In general, with the increase in the class level, the percentage of correct responders increased, except for the 6th grade. If these results are evaluated, approximately half of fifth grade students cannot determine the hierarchical relationship of parallelograms with other quadrilaterals. 6th grade students were also found to be more unsuccessful in determining the hierarchical relationship of other parallelograms with other special quadrilaterals than the other class levels. 5th and 6th grade students were found to give similar answers when examining the incorrect answers. When the answers of 5th and 6th grade students were examined, they stated that the rhombus is not a parallelogram, because rhombus has four equidistant sides but parallelogram has not. Similarly for rectangles, students answered formally by linking the absence of perpendicular angles of a parallelogram. For square, same students answered that square has the four equal-length sides and four perpendicular angles but parallelograms have not. This indicates that students consider each quadrilateral independently of each other and they don't classify them hierarchically. As a matter of fact, similar results can be seen in their studies on different class levels of De Villiers (1994), Okazaki and Fujita (2007), Ergün (2010), Aktas and Cansız Aktas (2012), Fujita (2012) and Türnükü, Alaylı and Akkaş. 7th and 8th grade students correctly point out the relationship between the parallelograms and the other special quadrilaterals. At all class levels, students cannot explain adequately when they look at the mathematical explanations about this situation. Students try to explain the relationship by using formal movements or they did not give any explanation. This result may be originated from the fact that students have not fully grasp the hierarchical relation between these special quadrilaterals in their minds. It is in fact expected that increase in class-level should induce the increase in awareness of the relationship of parallelogram with other special quadrilaterals. Because students in this class correspond to the second level of the van Hiele Geometry Thinking Levels, when students are provided with appropriate learning environments, students are able to recognize the hierarchy of shapes.

When the results of the two questions are evaluated together, the correct recognition ratios in the 6th, 7th and 8th grade levels is parallel to the correct determination rates in relation to some other special quadrilaterals. While the 7th grade students were relatively more successful than the 8th grade students in the determination of parallelogram, the 8th grade students were found to be more successful than the 7th grade students in determining the hierarchical relationship with the other special quadrilaterals. It has been seen that 5 th grade students are relatively more successful in determining the hierarchical relationship of parallelograms with some other special quadrilaterals than in defining parallelograms.

When the relation between the level of recognition of parallelogram by the secondary school students and the determinations of the relation with some other special quadrilaterals is statistically examined, it is seen that the number of respondents towards the statement of "a trapezoid is a parallelogram" increases in parallel with the 
recognition levels. Likewise, almost all of the students at the hierarchical level answered correctly for the statement "rhombus is a parallelogram", while students at level 0 and Prototypical level answered more correctly than students at Prototypical level. Level 0 and hierarchical level students answered correctly at a high rate for the statement "a rectangle is a parallelogram". At this point, it is noteworthy that the students at level 0 respond more correctly to prototypical and partly prototypical students than to the students at the level. The reason for this is that students at this level have to consider the geometric forms completely according to their appearance. For this reason, it can be thought that rectangles are similar to parallelograms. A similar situation is also seen in the responses to the statement that "a square is a parallelogram". Almost all of the students at the hierarchical level responded correctly, while the students at level 0 were found to be more successful than Prototypical and partially prototypical students. It was determined that there was a statistically significant difference in all the statemants between the determination of the relationship and students' recognition level. It was seen that the students who were at the hierarchical level in all questions were more successful than the students at the other level in correctly determining the relation of the parallelogram with some other special quadrants. Another conclusion is that prototypical and partially prototypical students in determining the relation of parallelogram with some other special quadrilaterals have similar results to each other in determining these relations correctly. Another noteworthy result is that in all other proposals, except for the statement of "a trapezoid is a parallelogram", students at Level 0 answered more successfully than Prototypical Level and Partially Prototypical Level students. This situation is considered to be due to the similarity of rhombus, rectangle and square to parallelogram in terms of shape.

From these results emerging in the research, the special forms of the parallelogram should be included in the instruction of the parallelogram as well as the Prototypical image. The students should be offered opportunities to enable their exploration, not the ready-made definitions. Appropriate learning environments should be provided by considering students' van Hiele geometry thinking levels in teaching quadrilaterals. In the instruction of quadrilaterals, some special teaching methods such as realistic mathematics education, problem based mathematics education should be also preferred. Furthermore, using concrete materials (geometry strips, geometry boards, etc.), dynamic geometry software (Geoegebra, Cabri etc.) and origami (paper folding) activities may provide a better understanding of the parallelograms.

A similar study can be conducted on high school and university students. Deeper results can be obtained by interviewing the students. In addition, a broader study involving other special quadrilaterals may be conducted. Also, some studies about how secondary school mathematics teachers teach quadrilaterals and parallelograms may be conducted.

\section{References}

Akkaş, E. N., \& Türnüklü, E. (2015). Ortaokul matematik öğretmenlerinin dörtgenler konusunda pedagojik alan bilgilerinin öğrenci bilgisi bileşeninde incelenmesi [Middle school mathematics teachers' pedagogical content knowledge regarding student knowledge about quadrilaterals]. Illköğretim Online, 14(2), 744-756.

Aktaş, D. Y., \& Cansız Aktaş, M. (2012). 8. Sınıf öğrencilerinin özel dörtgenleri tanıma ve aralarındaki hiyerarşik siniflamay1 anlama durumları [Eighth grade students' understanding and hierarchical classification of quadrilaterals]. İlköğretim Online, 11(3), 714-728. https://doi.org/10.17051/io.2015.12002

Aktaş, M. C., \& Aktaş, D. Y. (2012). Öğrencilerin dörtgenleri anlamaları: paralelkenar örneği [Students' understanding of quadrilaterals: the sample of parallelogram]. Ĕgitim ve Öğretim Araştırmaları Dergisi, 1(2), 319-329.

Altun, M. (2008). İlköğretim İkinci Kademede (6, 7 ve 8. sinıflarda) Matematik Öğretimi [Teaching mathematics in the second level of primary education (grades 6,7 and 8)]. Bursa: Alfa Yayıncilık.

Aydoğdu-İskenderoğlu, T., \& Baki, A. (2011). İlköğretim 8.sınıf matematik ders kitabındaki soruların PISA matematik yeterlik düzeylerine göre sinıflandırılması [Classification of the questions in an 8th grade mathematics textbook with respect to the competency levels of PISA]. Egitim ve Bilim, 36(161), 287-301.

Baki, A. (2008). Kuramdan uygulamaya matematik eğitimi [Mathematics education from theory into practice]. Ankara: Harf Eğitim Yayıncıllı̆ı.

Başışık, H. (2010). İlköğretim 5.sınıf öğrencilerini çokgenler ve dörtgenler konularındaki kavram yanılgılarının belirlenmesi [Determining fifth grade students` misconceptions on polygons and quadrilaterals]. Unpublished master thesis. Adnan Menderes Üniversitesi, Sosyal Bilimler Enstitüsü, Aydın. 
Baykul, Y. (2005). Ilköğretimde Matematik Öğretimi (1-5. Sinıflarda)[Mathematics education in primary schools (Grades 1 to 5)]. Ankara: Pegem Yayıncılık.

Berkün, M. (2011). İlköğretim 5 ve 7. Sınıf öğrencilerinin çokgenler üzerindeki imgeleri ve sınıflandırma stratejileri [The images of polygons and classification strategies for the primary school students of 5th and 7th grades]. Unpublished master thesis. Dokuz Eylül Üniversitesi, Eğitim Bilimleri Enstitüsü, İzmir.

Bowen, G. A. (2009). Document analysis as a qualitative research method. Qualitative research journal, 9(2), 27-40. https://doi.org/10.3316/QRJ0902027

Cohen, L., Manion, L., \& Morrison, K. (2000). Research methods in education. London: Routledge.

Cohen, L., Manion, L., \& Morrison, K. (2007). Research methods in education (6th ed.). New York, NY: Routledge.

Çepni, S. (2007). Araştırma ve proje çalışmalarına girişs [Introduction to research and projects]. Trabzon: Celepler Matbaacilık.

Dane, A., \& Başkurt, H. (2011). İlköğretim 6,7 ve 8. Sınıf Öğrencilerinin Doğru Parçası, Doğrusallık, Işın ve Açı Kavramlarını Algılama Düzeyleri [Primary school the 6th, 7th and 8th grade students' perceptions on line segment, linearity, ray and angle concepts]. Erzincan Eğitim Fakültesi Dergisi, 13(2), 85-104.

De Villiers, M. (1994). The role and function of a hierarchical classification of quadrilaterals. For the learning of mathematics, 14(1),11-18.

Erez, M., \& Yerushalmy, M. (2006) "If you can turn a rectangle into a square, you can turn a square into a rectangle": young students' experience the dragging tool. International Journal of Computers for Mathematical Learning, 11(3), 271-299. https://doi.org/10.1007/s10758-006-9106-7

Ergün, S. (2010). İlköğretim 7. sınıf öğrencilerinin çokgenleri algılama, tanımlama ve sınıflama biçimleri [7th grade students' perception, definition and classification of the polygons]. Unpublished master thesis. Dokuz Eylül Üniversitesi, Eğitim Bilimleri Enstitüsü, İzmir.

Erşen, Z. B., \& Karakuş, F. (2013). Sınıf öğretmeni adaylarının bazı dörtgenlere yönelik tanımlama ve siniflamalarının incelenmesi [Examining pre-service primary school teachers' definitions and classifications towards quadrilaterals] Karaelmas Journal of Educational Sciences, 4(2), 38-49.

Fujita, T. (2012). Learners' level of understanding of inclusion relations of quadrilaterals and Prototypical phenomenon. The Journal of Mathematical Behavior, 31, 60-72. https://doi.org/10.1016/j.jmathb.2011.08.003

Fujita, T., \& Jones, K. (2006). Primary trainee teachers' understanding of basic geometrical figures in scotland. In J. Novotana, H. Moraova, K. Magdelena \& N. Stehlikova (Eds.), Proceedings of The 30th Conference of the International Group for the Psychology of Mathematics Education, 3, 14-21. Charles University: Prague.

Fujita, T., \& Jones, K. (2007). Learners' understanding of the definitions and hierarchical classification of quadrilaterals: Towards a theoretical framing. Research in Mathematics Education, 9(1), 3-20. https://doi.org/10.1080/14794800008520167

Jones, K. (2002). Issues in the Teaching and Learning of Geometry. In: Linda Haggarty (Ed.), Aspects of Teaching Secondary Mathematics: perspectives on practice. London: RoutledgeFalmer. 121-139.

Karakuş, F., \& Erşen, Z. B. (2013). Sınıf öğretmeni adaylarının dörtgenlere yönelik kavram imajlarının değerlendirilmesi [Evaluation of preservice elementary teachers' concept 1mages for quadrilaterals]. Turkish Journal of Computer and Mathematics Education, 4(2), 124-146.

MEB (2016). Pisa 2015 Ulusal Raporu. [National PISA 2015 report] Retrieved 02.04.2017 from http://pisa.meb.gov.tr/wp-content/uploads/2016/12/PISA2015_Ulusal_Rapor1.pdf

MEB. (2013). Illkokul matematik dersi 1-4. Siniflar ögretim programı [Primary schools grades 1-4 mathematics curriculum] Ankara: MEB Talim ve Terbiye Kurulu Başkanlığı.

MEB. (2015). Ortaokul matematik dersi 5-8. Sinıflar ögretim programı. [Elementary schools grades 5-8 mathematics curriculum] Ankara: MEB Talim ve Terbiye Kurulu Başkanlığı.

MEB. (2017). Matematik dersi ögretim programı (İlkokul ve ortaokul 1, 2, 3, 4, 5, 6, 7 ve 8. Sinıflar). Ankara: Milli Eğitim Bakanlı̆̆

Miles, M. B., \& Huberman, A. M. (1994). Qualitative Data Analysis. Thousand Oaks, CA: Sage Publication.

Monaghan, F. (2000). What difference does it make? Children's views of the differences between some 
guadrilaterals. Educational studies in mathematics, 42(2), 179-196. https://doi.org/10.1023/A:1004175020394

Okazaki, M., \& Fujita, T. (2007). Prototypical phenomena and common cognitive paths in the understanding of the inclusion relations between quadrilaterals in Japan and Scotland. In H. Woo, K. Park \& D. Seo (Eds.), Proceedings of The 31st Conference of the International Group for the Psychology of Mathematics Education, 4, 41-48. The Korea Society of Educational Studies in Mathematics: The Republic of Korea.

Özkan, M. (2015). 7. sınıf öğrencilerinin çokgenlerde ve özel dörtgenlerde yaptıkları kavram yanılgılarının incelenmesi [Analysing the misconceptions that students have about polygon and special quadrilaterals]. Unpublished master thesis. Çukurova Üniversitesi, Sosyal Bilimler Enstitüsü, Adana.

Pickreign, J. (2007). Rectangle and Rhombi:How Well do Pre-service Teachers Know Them? Issues in the Undergraduate Mathematics Preparation of School Teachers, 1, Content Knowledge. Retrieved 02.04.2017 from http://www.k-12prep.math.ttu.edu

Pusey, E. L. (2003). The Van Hiele model of reasoning in geometry: a literature review. Unpublished master thesis. North Carolina State University.

Türnüklü, E. (2014). Dörtgenlerde aile ilişkilerinin yapılandırılması: ilköğretim matematik öğretmeni adaylarının ders planlarının analizi [Construction of inclusion relations of quadrilaterals: analysis of pre-service elementary mathematics teachers' lesson plans]. Eğitim ve Bilim, 39(173), 197-207.

Türnüklü, E., Alaylı, F. G., \& Akkaş, E. N. (2013). İlköğretim matematik öğretmen adaylarının dörtgenlere ilişkin algiları ve imgelerinin incelenmesi [Investigation of prospective primary mathematics teachers' perceptions and 1mages for quadrilaterals]. Kuram ve Uygulamada Ë̆itim Bilimleri, 13(2), 1213-1232.

Ubuz, B., \& Üstün, I. (2003). Figural and conceptual aspects in identifying polygons. In N.A. Pateman, B.J. Dougherty \& J.T. Zilliox (Eds.), Proceedings of the 27th International Conference for the Psychology of Mathematics Education, 1. University of Hawaii: Honolulu.

Üstün, I., \& Ubuz, B. (2004). Geometrik Kavramların Geometer's Sketchpad Yazılımı ile Geliştirilmesi [Development of geometric concepts using Geometer's Sketchpad]. In Ü. Ergüder (Ed.), Eğitimde İyi Örnekler Konferansi Bildiri Özetleri (Proceedings of conference of best examples in education) Sabanc1 University: İstanbul.

Van Hiele, P. M. (1986). Structure and Insight: A Theory of Mathematics Education. Academic Press: Orlando.

Yıldırım, A., \& Şimşek, H. (2008). Sosyal bilimlerde nitel araştırma yöntemleri. [Qualitative research methods in social sciences]. Ankara: Seçkin Yayıncılık. 
Appendix-1. Data Collection Tool

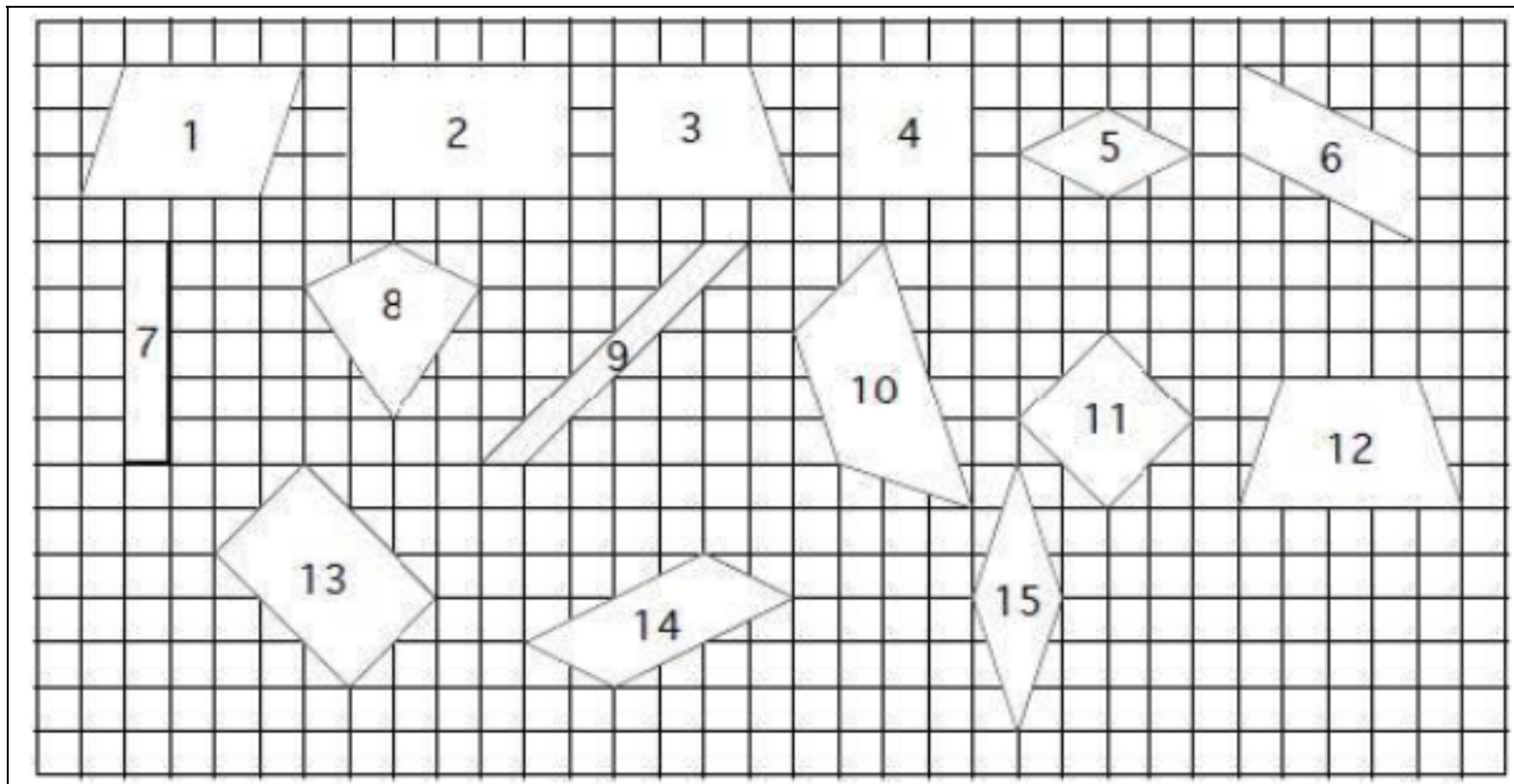

1) Yukarıda numaralandırılmış olarak verilen şekillerden hangisi veya hangileri paralelkenardır? Aşağıya numaralarını yazınız.

2) Aşağıdaki cümleleri dikkatlice okuyunuz. Karşısındaki evet ya da hayırdan birini işaretleyiniz. Cevabınız ne olursa olsun yan tarafindaki kutucuğa açıklama yazınız.

$>$ Yamuk bir paralelkenardir. Evet ( ) $\square$ Açıklama:

(2)

$>$ Eşkenar dörtgen bir paralelkenardır. Evet ( ) $\longrightarrow$

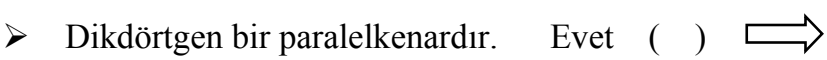

$>$ Kare bir paralelkenardır. Evet $(\quad)$ Açıklama: 